\title{
Diversity and Conservation Status of Fish Fauna in Freshwater Lake of Kamalapur, Karimnagar District, Telangana, India.
}

\author{
${ }^{1}$ M.Thirupathaiah, ${ }^{1}$ Chintta.Samatha and ${ }^{1} \mathrm{Ch}$. Sammaiah \\ ${ }^{I}$ Department of Zoology, Kakatiya University Warangal, India
}

\begin{abstract}
The present paper deals with the diversity, abundance and IUCN status of fresh water fish fauna in freshwater Lake of Kamalapur, Dist Karimnagar. Samples were collected monthly with help of local fishermen by using fishing nets. Total of 25 fishes are belonging to 7 orders, 11 families and 18 genera. Among fishes order Cypriniformes was most dominant with 11 fish species followed by order Siluriformes with six species, the order Perciformes with three species, Symbranchiformes with two species and Ostoeoglossiformes, Beloiniformes and Anguilliformes one species each. Of these, 13 species of fish are least concerned, 4 are data deficient (DD), 6 are not evaluate (NE), 1 species of fish is vulnerable and one species of fish is near threatened. Shannon-Weiner diversity $\left(H^{-}\right)$and Evenness $(J)$ for different months were calculated.
\end{abstract}

Keywords: Kamalapur fresh water lake, Fish diversity, Shannon-Weiner diversity $(H)$, Evenness $(J)$ and IUCN status.

\section{INTRODUCTION}

Biodiversity is essential for stabilization of ecosystem, protection of overall environmental quality, for understanding intrinsic worth of all species on the earth [1]. It is the quantity, variety and distribution across biological scales ranging through, genetics and life forms of population, species, community and ecosystem. Fishes are very important form the biodiversity point of view and are the best bio-indicators of the ecosystem [2]. They are one of the prime important elements in the aquatic habitat and play a key role in economy of many nations as they have been a stable item in the diet of many people [3]. Fishes provide cheap source of protein of animal origin, fat, vitamin A and D minerals [4]. As animal proteins consumed by 1 billion people worldwide [5]. India is one of the mega biodiversity hot spots contributing $11.72 \%$ of the globe fish biodiversity. Out of these 400 species are commercial important, which cultural, cultivable and wild. On the global scale, Indian fish represent $11 \%$ of species, $24 \%$ of genera and $57 \%$ of families [6].

The fish fauna of Andhra Pradesh has been reported by several workers [7-12]. Present investigations were under taken to study the fish biodiversity and the fish abundance of fishes was evaluated and their IUCN status and measures of conservation of Kamalapur's fresh water lake.

\section{MATERIALS AND METHODS}

Study area: The Kamalapur lake is located west side of village, it is in capable of storing up 700 million cubic meters of water that can be used for agricultural the lake receives most of water from small canals. The catchment area of the lake is agricultural fields (dry and wet) and receiving the agricultural wastages. The present study was carried out in freshwater lake of Kamalapur is located at latitude $\left(14^{0} 36^{\prime} \mathrm{N}\right)$ longitude $\left(78^{0} 42^{\prime} \mathrm{E}\right)$ Kamalapur village in Karimangar (Fig-1).

Collection of fish sample: The collections were made once in a week from 4 points of the lake during Oct-2011 to Sep-2012 with the help of local fishermen using different types of nets namely gillnets, casts nets and dragnets. The collected fishes were photographed labeled and preserved in 10\% Formalin solution and brought to the laboratory. Smaller fishes were directly placed in the $10 \%$ formalin solution while large fishes were given an incision on the abdomen before they were fixed. The fishes were identified with help of standard reference material [13-15]. The qualitative and quantitive analysis of fish species was carried out. Species ShannonWiener index $\left[\mathrm{H}=-\sum \mathrm{P}_{\mathrm{i}} \log \mathrm{P}_{\mathrm{i}}\right]$ and Evenness index $\left[\mathrm{J}=\mathrm{H} / \mathrm{H}_{\max }\right]$ were worked out.

Shannon-Weiner index: $\mathrm{H}=-\sum \mathrm{P}_{\mathrm{i}} \log \mathrm{P}_{\mathrm{i}}$ Where, $\mathrm{H}=$ Shannon - Weiner index, $\mathrm{Pi}=\mathrm{ni} / \mathrm{N}, \sum=\mathrm{Sum}, \mathrm{ni}=$ Number of individuals of each species in the sample, $\mathrm{N}=$ Total number of individuals of all species in the sample. Evenness: $\mathrm{J}=\mathrm{H} / \mathrm{H}_{\max }$ Where, $\mathrm{J}=$ Evenness index, ' $\mathrm{H}$ ' is the Shannon - Weiner index, $\mathrm{H}_{\max } \log \mathrm{S}$, ' $\mathrm{S}$ ' is the number of species.

\section{RESUlTS AND DisCUSSION}

In the result of present study, 25 species of 18 different genera 11 families and 7 orders were recorded from Kamalapur fresh Water Lake. They are Amblypharyngodon mola, Puntis chola, Puntis sophore, Puntis sarana, Salmostoma bacaila, Salmostoma phulo, Catla catla, Cirrhinus reba, Cirrhinus mrigala, Cyprinus carpio, Labeo rohita, under Cypriniformes, Mystus bleeker, Mystus seenghala, Ompok bimaculatus, Wallago 
attu, Clarias batrachus Heteropneustes fossilis under Siluriformes, Channa punctatus, Channa straiatus, Channa marulius, Glosogobius giuris under Perciformes Mastacembelus armatus, Mastacembelus pancalus, under Synbranchiformes, Anguilla bicolor under Angulliformes, Notopterus notopterus under Osteoglossiformes, Xenentodon cancila, under Beloiniformes, A systematic list of fishes observed from the Kamalapur fresh water lake has been provided in table-1.

The relative abundance of the fish was classified into three categories, namely; abundant $(76 \%-100 \%$ of the total catch), Less abundant (26\% - 75\% of the total catch) and rare (1\% - 25\% of the total catch) [16-17]. Cypriniformes was dominant with 11 species was dominant group in the assemblage composition in which $A$. mola, C. catla, L. rohita,P.chola C. mrigala,S.bacaila and S. phulo were found abundant. C. carpio, and $P$. sophore were found in less abundant form. C.reba and P. sarana were found in rare. Followed by Siluriformes in which W. attu, O. bimaculatus, and M. bleekeri were found in abundant form, C.batrachus and H. fossilis were found in less abundant form M. seenghala was found in rare form. Osteoglossiformes in which one species found that is $N$. noteperus less abundant form. Perciformes in which C.punctatus, C. striata and G. giuris were found in abundant. Beloniformes in which one species fount that is $X$. cancila also abundant. Synbranchiformes in which M. pancalus and M. armatus were found in less abundant form. Anguiliformes in which one species found that is Anguilla bicolor rare shown in the table-1

The monthly percentages of different orders of fishes are presented during October 2011 to September 2012 in (Fig-2). The maximum percentage of Cypriniformes (60\%) was recorded in April and minimum $(46.23 \%)$ represented in December. In Siluriformes was maximum percentage $(24.8 \%)$ of recorded in October and minimum percentage (13.55\%) in March. In case of Angulliformes maximum percentage (5.45\%) recorded in April and minimum percentage (1.66\%) in February, not recorded any Angulliformes species in October. The maximum percentage (5.26\%) of Osteoglossiformes recorded in May and minimum percentage $(1.81 \%)$ in month of April. Beloiniformes recorded maximum percentage (7.89\%) in May and minimum (3.09\%) in June. Perciformes recorded the maximum percentage (20.5\%) of in January and minimum (11.83\%) in August. Seasonal dynamics of the fish population showed that high value of fish diversity during rainy and winter months in the present study (Fig-3) [21], which implied that lake receive large volume of less polluted and high oxygenated water which favoring the improvement of fish growth and most of the fishes migrate for breeding. During summer when water flows is greatly reduced in to lake appears to be devoid fish. The fish fauna is not uniform and seasonal variation has been observed from this habitat [22].

Number and percent composition of families, genera and species under various orders are presented in (table-2 and Fig-4). As far as the genera and families to different orders are concerned order cypriniformes consists of seven genera $(38.88 \%)$ under one family $(9.09 \%)$, Siluriformes of five genera $(27.77 \%)$ under four families $(36.36 \%)$, Perciformes of two genera $(11.11 \%)$ under two families (18.18\%), Angulliformes, Osteoglossiformes and Beloniformes of single genera $(5.55 \%)$ under single family(9.09\%) each (Table-2 and Fig-5).

Order Cypriniformes has been found to be a major order with 11 species and percent contribution of $44 \%$. Siluriformes comes next with 6 species and percent contribution of 24\%. Perciformes with two species and percent contribution of $12 \%$. Angulliformes, Osteoglossiformes and Beloniformes with one species each and percent contribution of $4 \%$ follow the order [23]. Order cypriniformes with 11 species showed maximum species diversity while the minimum fish species diversity was shown by order Beloniformes, Osteoglossiforms and Anguliformes with only one species [24].

Number and percent composition of genera and species under various families are presented in (Table3). The generic composition of fishes belonging to different families shows that seven genera under Cyprinidae contribute to $38.88 \%$, two genera under Siluridae contribute to $11.11 \%$ and one genus each under Bagridae, Claridae, Heteropneustidae, Gobiidae, Belonidae, Angulillidae, Notopteridae, Ohannidae and Mastacembelidae contribute to $5.55 \%$ each. The species composition of fishes belonging to different families has revealed that 11 species are belonging to family cyprinidae that made up to $44 \%$, two species each to family Bagridae, Siluridae, Channidae and Mastacembelidae making to $8 \%$ and one species each to families Schilbeidae, Claridae Heteropneustidae, Anguillidae, Notopteridae, Belonidae and Gobiidae contributing 4\% each of total fish species [25] (Table-3). Many authors have estimated the percentage composition of families among various orders. The maximum contribution is of family Cyprinidae which is up to $39.58 \%$ [26], up to $45.71 \%$ [27], up to 53.65\% [28], up to $47.82 \%$ [29], up to $40.90 \%$ [12] have been reported.

Among all the 25 species recorded in Kamalapur lake one species (Cyprinus carpio) was exotic and others species were indigenous to Telangana. According to the CAMP [18], 9 species of fish are Lower risk near threatened (LR-nt), six species of fish are Vulnerable (VU), two species of fish is Lower risk least concern(LRlc) and one species of fish is Endangered (EN). According to the IUCN [20], one species is Near threatened, one is Vulnerable, four are data deficient (DD), six are not evaluate (NE) and rest 13 are Least concerned were found [30] (Table-1). 
Diversity indices of fish species in Kamalapur Lake presented (Table-4). The fish species diversity $\left(\mathrm{H}^{-}\right)$ ranged from 2.47 to 7.074. The highest diversity was recorded in September 2012 the lowest in July 2012. These results indicate good diversity. According to Wilhm and Dorris [31] Shannon index $\left(\mathrm{H}^{-}\right)$values ranged from $>3$ indicates clean water. 1.00 to 3.00 indicates moderate water and <1.00 indicates heavily polluted water. The fish species diversity $(\mathrm{J})$ ranged from 1.376 to 3.331 . The highest diversity was recorded in October 2012 and lowest in July 2012. It is clearly indicate that there is evenly distribution of the fish fauna. The biotic indices of Shannon-Weiner and Evenness were fairly significant in during study period.

Conservation: Conservation steps have been found during present investigation that the stopping illegal fishing, identifying illegal protecting crucial breeding habitats, creating mass awareness are need to save the threatened fish fauna of this lake, also fishermen and protecting divers fish resources.

\section{FIGURES AND TABLES}

INDIA

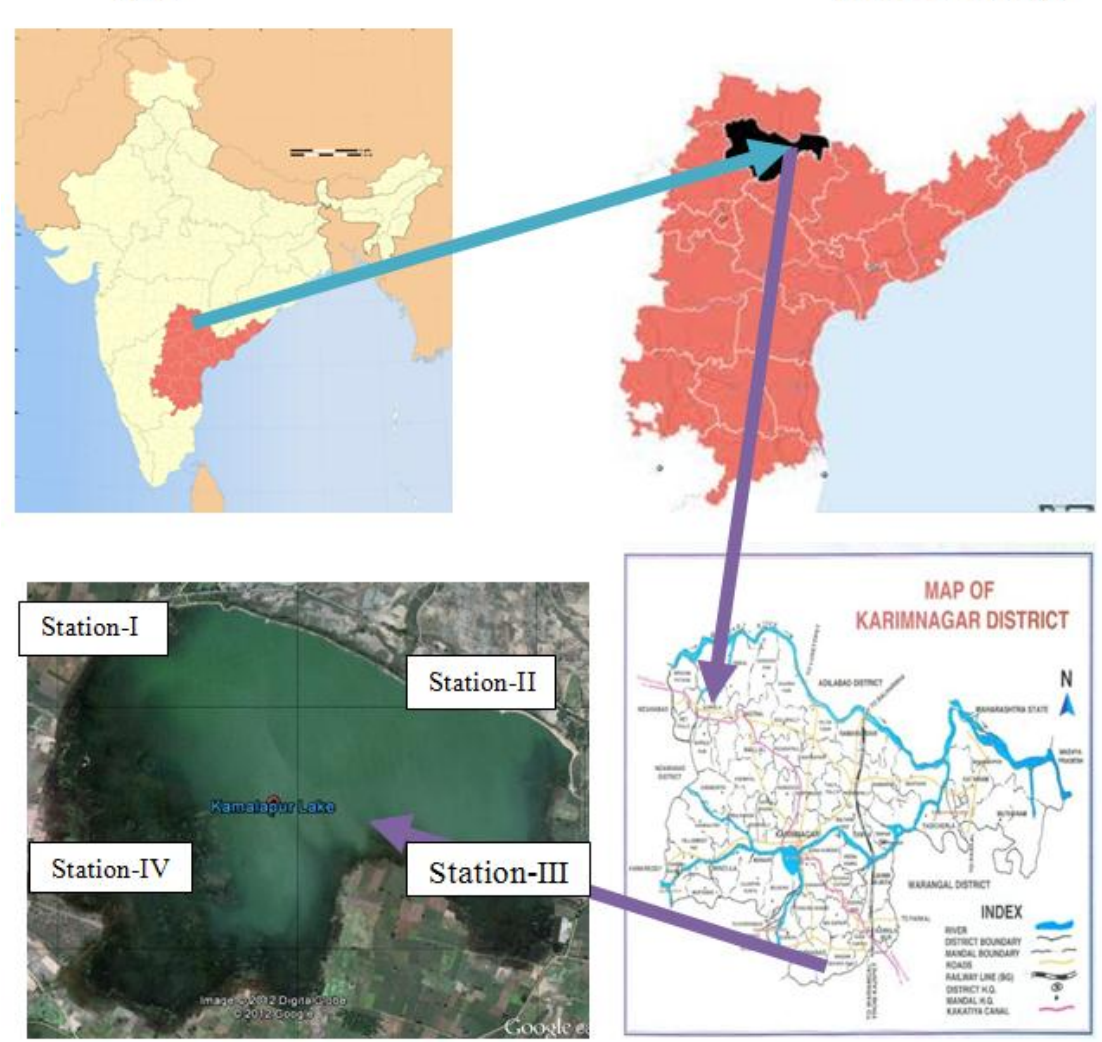

Fig-1. Map showing Kamalapur lake in Kamalapur village, Karimnagar district, A.P, India.

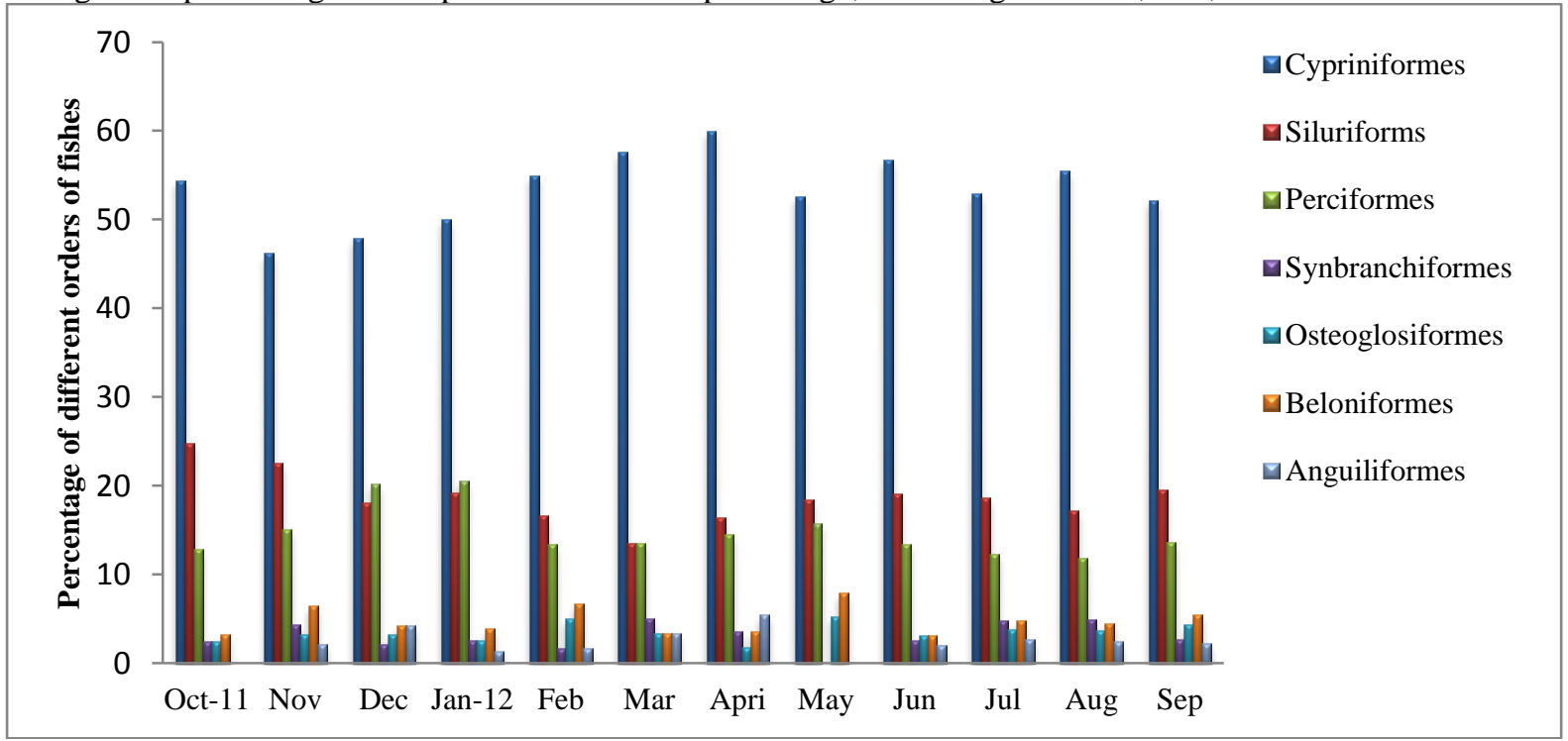

Fig -2. Order-wise monthly percentage of different fishes (October-2011 to September 2012) 


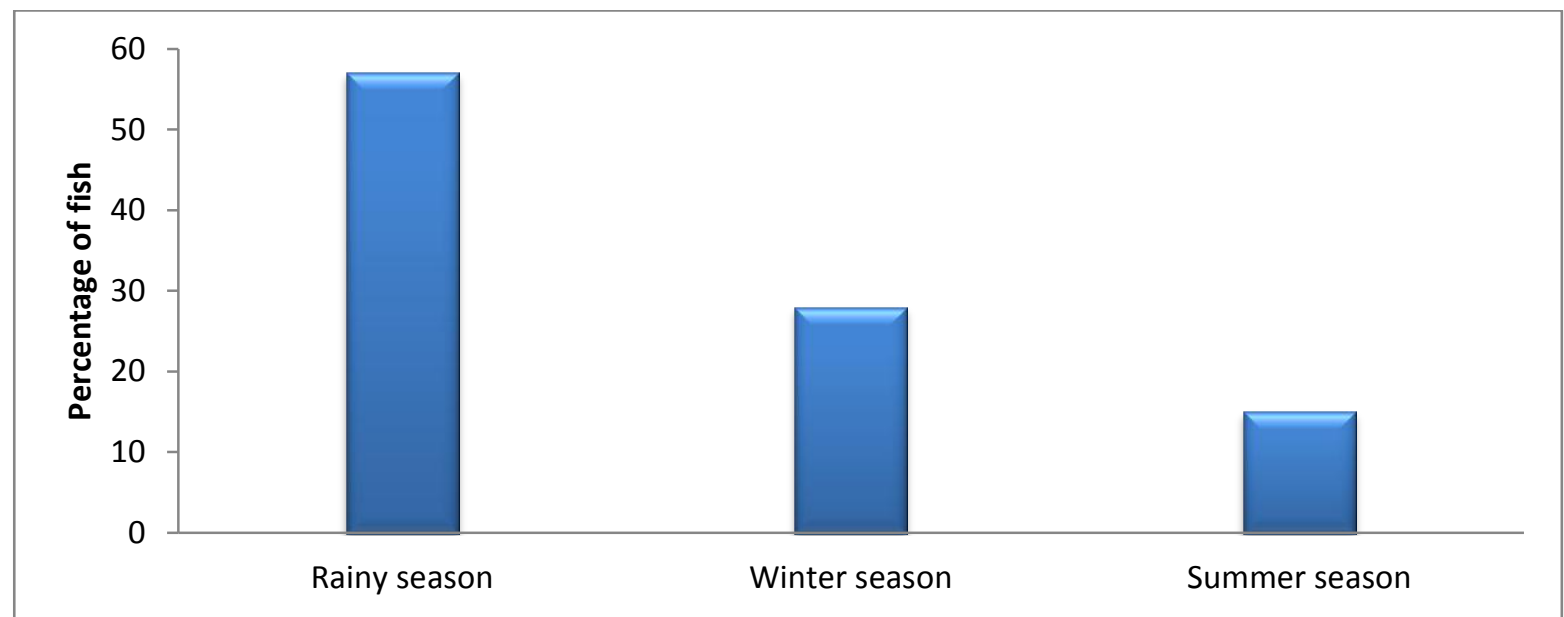

Fig-3.Seasonal wise distribution of fish fauna of the Kamalapur lake.

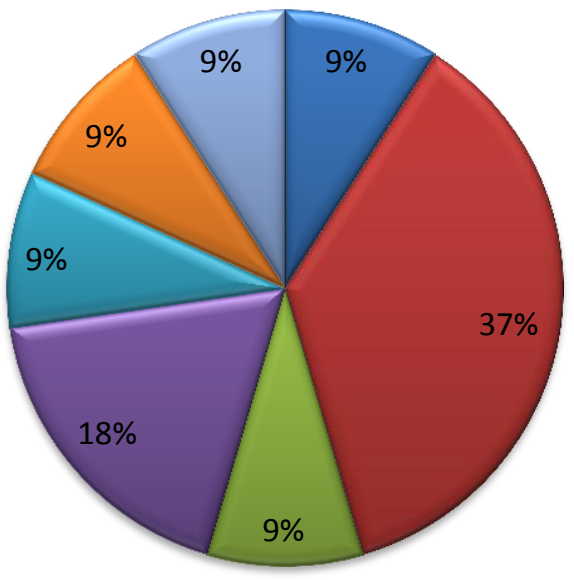

DCypriniformes

Siluriforms

$\square$ Perciformes

QSynbranchiformes

Osteoglosiformes

$\square$ Beloniformes

$\square$ Anguiliformes

Fig-4. Showing percent contribution of families to the orders

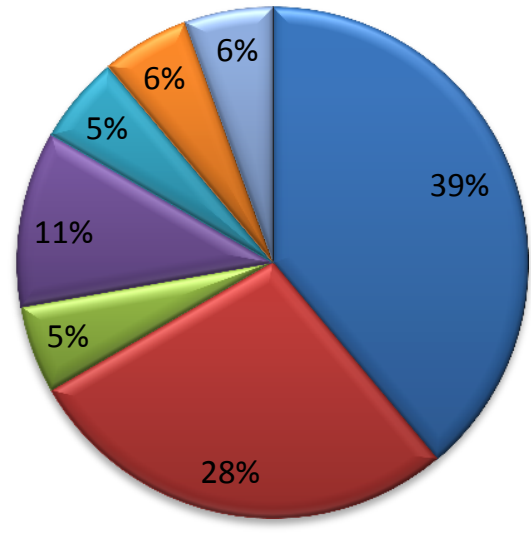

- Cypriniformes

Siluriforms

$\square$ Perciformes

- Synbranchiformes

DOsteoglosiformes

$\square$ Beloniformes

$\square$ Anguiliformes

Fig-5. Number showing percent contribution of genera to the orders. 
Diversity And Conservation Status Of Fish Fauna In Freshwater Lake Of Kamalapur, Karimnagar

Table 1: List of fishes recorded in Kamalapur Lake with their CAMP, 1998 status, CAFF (2006) status and IUCN status.

\begin{tabular}{|c|c|c|c|c|c|}
\hline Order and Family & Species & CAMP [18] & CAFF [19] & $\begin{array}{l}\text { Www.iucnredlist.org } \\
{[20] .}\end{array}$ & Status \\
\hline \multicolumn{6}{|l|}{ Cypriniformes } \\
\hline \multirow[t]{11}{*}{ Cyprinidae } & 1. Amblypharyngodon mola (Hamilton) & LR-lc & LR-lc & $\mathrm{LC}$ & $\mathrm{A}$ \\
\hline & 2. $\quad$ Catla catla (Hamilton) & $\mathrm{VU}$ & LR-nt & $\mathrm{NE}$ & $\mathrm{A}$ \\
\hline & 3. $\quad$ Cirrhinus mrigala (Hamilton) & LR-nt & LR-nt & $\mathrm{LC}$ & A \\
\hline & 4. Cirrhinus reba (Hamilton) & VU & VU & $\mathrm{LC}$ & $\mathrm{R}$ \\
\hline & 5. Cyprinus carpio carpio (Linnaus) & & & VU & LA \\
\hline & 6. $\quad$ Labeo rohita (Hamilton) & LR-nt & LR-lc & LC & A \\
\hline & 7. Puntius chola (Hamilton) & & & $\mathrm{LC}$ & A \\
\hline & 8. $\quad$ Puntius sarana sarana (Hamilton) & $\mathrm{VU}$ & $\mathrm{VU}$ & $\mathrm{LC}$ & $\mathrm{R}$ \\
\hline & 9. $\quad$ Puntius sophore (Hamilton) & LR-nt & LR-nt & $\mathrm{LC}$ & LA \\
\hline & 10. Salmostoma bacaila (Hamilton) & LR-lc & DD & $\mathrm{LC}$ & $\mathrm{A}$ \\
\hline & 11. Salmostoma phulo (Hamilton) & & & $\mathrm{NE}$ & \\
\hline \multicolumn{6}{|l|}{ Siluriformes } \\
\hline \multirow[t]{2}{*}{ Bagridae } & 12. Mystus seenghala(Sykes) & $\mathrm{NE}$ & LR-nt & $\mathrm{NE}$ & $\mathrm{R}$ \\
\hline & 13. Mystus bleekeri (Day) & $\mathrm{VU}$ & $\mathrm{VU}$ & DD & A \\
\hline \multirow[t]{2}{*}{ Siluridae } & 14. Wallago attu (Schneider) & LR-nt & LR-nt & NT & A \\
\hline & 15. . Ompok bimaculatus (Bloch) & EN & EN & $\mathrm{DD}$ & $\mathrm{A}$ \\
\hline Clariidae & 16. Clarias batrachus (Linnaeus) & VU & VU & LC & LA \\
\hline Heteropneustidae & 17. Heteropneustes fossilis (Bloch) & VU & VU & $\mathrm{LC}$ & LA \\
\hline \multicolumn{6}{|l|}{$\begin{array}{l}\text { Osteoglossiforme } \\
\mathrm{s}\end{array}$} \\
\hline Notopteridae & 18. $\quad$ Notoperus noteperus (Pallas) & LR-nt & EN & $\mathrm{LC}$ & LA \\
\hline \multicolumn{6}{|l|}{ Perciformes } \\
\hline \multirow[t]{2}{*}{ Channidae } & 19. Channa punctatus (Hamilton) & LR-nt & LR-nt & $\mathrm{NE}$ & $\mathrm{A}$ \\
\hline & 20. Channa striata (Bloch) & LR-nt & LR-nt & $\mathrm{NE}$ & A \\
\hline Gobbidae & 21. Glosogobius giuris (Hamilton) & & & $\mathrm{DD}$ & A \\
\hline \multicolumn{6}{|l|}{ Beloniformes } \\
\hline Belonidae & 22. Xenetodon cancila(Hamilton) & LR-nt & LR-nt & $\mathrm{LC}$ & A \\
\hline \multicolumn{6}{|l|}{$\begin{array}{l}\text { Synbranchiforme } \\
\text { s }\end{array}$} \\
\hline \multirow[t]{2}{*}{ Mastacembelidae } & 23. Mastacembelus pancalus (Hamilton) & LR-nt & LR-nt & $\mathrm{NE}$ & LA \\
\hline & 24. Mastacembelus armatus (Lacepede) & $\mathrm{NE}$ & $\mathrm{VU}$ & $\mathrm{LC}$ & LA \\
\hline \multicolumn{6}{|l|}{ Anguiliformes } \\
\hline Anguillidae & 25. Anguilla bicolor & & & $\mathrm{DD}$ & $\mathrm{R}$ \\
\hline
\end{tabular}

EN (Endangered), Vu (Vulnerable), Lr-nt (Lower risk near threatened), LR-lc (Lower risk least concern), NE (Not evaluate), DD (Data defifient), LC (least concern) and NT (Near threatened), A (Abundant), LA (Less abundant) and $\mathrm{R}$ (Rare).

Table-2. Number and percent composition of families, genera and species under various orders

\begin{tabular}{|r|l|l|l|l|l|l|l|}
\hline $\begin{array}{l}\text { S.N } \\
\text { o }\end{array}$ & Order & Families & Genera & Species & $\begin{array}{l}\text { \% of families } \\
\text { in an order }\end{array}$ & $\begin{array}{l}\text { \% of genera } \\
\text { an order }\end{array}$ & $\begin{array}{l}\text { \% of species } \\
\text { in an order }\end{array}$ \\
\hline 1 & Cypriniformes & 1 & 7 & 11 & 9.09 & 38.88 & 44 \\
\hline 2 & Siluriformes & 4 & 5 & 6 & 36.36 & 27.77 & 24 \\
\hline 3 & Osteoglossiformes & 1 & 1 & 1 & 9.09 & 5.55 & 4 \\
\hline 4 & Perciformes & 2 & 2 & 3 & 18.18 & 11.11 & 12 \\
\hline 5 & Beloniformes & 1 & 1 & 1 & 9.09 & 5.55 & 4 \\
\hline 6 & Synbranchiformes & 1 & 1 & 2 & 9.09 & 5.55 & 8 \\
\hline 7 & Anguiliformes & 1 & 1 & 1 & 9.09 & 5.55 & 4 \\
\hline
\end{tabular}

Table-3. Number and percent composition of genera and species under various families

\begin{tabular}{|l|l|l|l|l|l|}
\hline S.No & Families & Genera & $\begin{array}{l}\text { \% Contribution of genera } \\
\text { to families }\end{array}$ & Species & $\begin{array}{l}\text { \% contribution of species to } \\
\text { families }\end{array}$ \\
\hline 1 & Cyprinidae & 7 & 38.88 & 11 & 44 \\
\hline 2 & Bagridae & 1 & 5.55 & 2 & 08 \\
\hline 3 & Siluridae & 2 & 11.11 & 2 & 08 \\
\hline 4 & Clariidae & 1 & 5.55 & 1 & 04 \\
\hline 5 & Heteropneustidae & 1 & 5.55 & 1 & 04 \\
\hline 6 & Notopteridae & 1 & 5.55 & 1 & 04 \\
\hline 7 & Channidae & 1 & 5.55 & 2 & 08 \\
\hline 8 & Belonidae & 1 & 5.55 & 1 & 04 \\
\hline 9 & Gobbidae & 1 & 5.55 & 1 & 04 \\
\hline 10 & Mastacembelidae & 1 & 5.55 & 2 & 08 \\
\hline 11 & Anguillidae & 1 & 5.55 & 1 & 04 \\
\hline
\end{tabular}


Table-4: Diversity indices of fish species in lake.

\begin{tabular}{|l|l|l|l|l|l|l|l|l|l|l|l|l|}
\hline Indices & Sep-11 & Oct & Nov & Dec & Jan-12 & Feb & Mar & April & May & June & July & Aug \\
\hline $\mathrm{H}^{-}$ & 7.074 & 2.74 & 2.863 & 2.843 & 2.778 & 2.914 & 2.793 & 2.448 & 2.96 & 2.47 & 2.992 & 3.044 \\
\hline $\mathrm{J}$ & 1.799 & 3.331 & 1.871 & 1.877 & 2.109 & 2.391 & 2.245 & 2.162 & 1.572 & 1.395 & 1.376 & 1.63 \\
\hline
\end{tabular}

$\mathrm{H}=$ Shannon-Weiner diversity index, J=Evenness diversity index,

\section{CONCLUSION}

The biotic indices of Shannon-Weiner and Evenness were fairly significant in during study period. The results of the present study are indicating that Kamalapur lake is a rich for fish species diversity. It indicate that this lake provide suitable environment for breeding, feeding and nesting. Therefore conservation measures are essential such as stopping illegal fishing, protecting mass awareness among fisherman to save the fish fauna of this lake.

\section{Acknowledgements}

The authors are thankful to the Head, Department of Zoology, Kakatiya University for providing necessary facilities to carry out the present work in Environmental Biology Lab.

\section{REFERENCES}

[1] Wilson EO (1992). Diversity of life, Birtib: W.W. \& Company, Inc. p. 242.

[2] Kumar Niraj (2012). Study of Ichthyofaunal Biodiversity of Turkaulia Lake, East-Chaparan, Bihar, India. I. Res. J. Environment Sci. 1 (2), 21-24.

[3] Essetchi, P.K., Guy, G.T., Valentin, N.D., Gouli, G.B.I. and Tidiani, K., (2003). Fish diversity and its relationships with environmental variables in a West African basin. Hydrobiology, 505: 139-146.

[4] Kumar Niraj and Singh N.P (2013). Studies on the Ichthyofauna of Kararia Lake of Motihari East-Champaran, Bihar, India. Res. J. Animal Veterinary and Fishery Sci, Vol. 1 (4), 8-12.

[5] Sallam KI. (2007). Chemical sensory and shelf life evaluation of sliced salmon treated with salts of organic acids. Food Chem. 101(2):592-600.

[6] NBSAP (2000). India Third National Report http//www.biodiv.org/doc/world/in/in-nr-03-en.pdf.

[7] Rahimullah, M. (1943). Fish Survey of Hyderabad State, Part-II. Fishes of Hyderabad city and its suburbs. Journal of the Bombay Natural History Society 44 (1\&2): 88-95.

[8] Zafer. A.R. (1966). Limnology of Hussain Sagar Lake. Hyderabad. India. Phykos, 5: 115-129.

[9] Rao, M., and Y.S. Reddy (1984). Fish fanua of Hussainsagar, Hyderaba. Jantu 2: 1-16.

[10] Barman, R.P. (1993). Pisces: Freshwater fishes. Pp. 89-334. In: State Fauna series 5, Fauna of Andhra Pradesh, Part-I. Zoological Survey of Inida.

[11] Chandrasekhar, S.V.A. (2004). Fish fauna of Hyderabad and its environs, Zoos' Print Journal, 19(7): 1530-1533.

[12] Sammaiah. Ch, Thirupathaiah and M, Samatha. Ch. (2013). Diversity of fish fauna in Lower Manair reservoir of Karimnagar District (A.P). India. Advance in Applied Science Research, 4(2):-203-211.

[13] Jayaram, K.C. (1981). The Freshwater Fishes of India, Pakistan, Bangladesh, Burma and Sri Lanka-A Hand Book. Director, Zoological Survey of India, Kolkata.

[14] Jayaram. K.C. (1999). The freshwater Fishes of the Indian Origin, Narendra Publishing House, Delhi-551.

[15] Talwar, P.K. and A.G. Jhingran (1991). Inland Fishes of India and Adjacent Countries, Vol. 1\&2. Oxford \& IBH Publishing Co. Pvt.Ltd., 1158pp.

[16] Jadhav. B.V., Kharat S.S., Raut R.N., Paingankar M., Dahanukar N. (2011). Freshwater fish fauna of Koyna River, northern Western Ghats, India. Journal of threatened taxa 3(1): 1449-1455.

[17] Radhakrishnan K.V., Kurup B.M. (2010). Ichthyodiversity of Periyar Tiger Reserve, Kerala, India. Journal of threatened taxa 2 (10): 1192-1198.

[18] CAFF. (2006). Organized by NBFGR, Lucknow at Bhopal.

[19] CAMP report. (1998). Conservation Assessment and Management Plan (C.A.M.P) Workshop, Freshwater fishes of India. NBFGR, Lucknow, 22-26 September. Pp.156.

[20] IUCN. (2013). Red List of threatened species, Version 2012.2 www.iucnredlist.org down loaded on 15 January.

[21] Prabaharan. C and Senthil Muragan. A. (2012). Fish diversity in relation to physic-chemical characteristics of Kamala Basin of Darbhanga District, Bihar, India. IJPBA. 3(1): 211-217.

[22] Tripathy Madhusmita (2012). Biodiversity of Chilika and its conservation, Odisha, India, Int.Res. J. Environment Sci., 1 (15) 5457.

[23] Garg R.K., Rao R.J., Saksena D.N. (2007). Checklist of fishes of Ramsagar reservoir, Datia District, Madhya Pradesh, India. Zoos' print journal 22 (8), 2801-2803.

[24] Shahnawaz A., Venkateshwarlu M. (2009). A check list of fishes from Tunga and Bhadra rivers, Karnataka, India with special note on their biodiversity status. Current biotica 3(2): 232-243 (2009).

[25] Sarma.D, Das. J, Goswami. U.C and Dutta A. (2012). Present Status and Habitat Ecology of Ompok pabo ( Ham-Buchanan) in Goronga Beel, Morigaon; Assam (India). Adv.Appl. Sci. Res., 3(1): 481-488.

[26] Dubey P.K., Maheshwari L.P., Jain A.K. (1980). J. Jiwaji University, 8(2), 113-122.

[27] Agarwal, S.S. and Saksena, D.N. (1977). A checklist of fishes from Gwalior, Madhya Pradesh. J. Jiwaji Univ., 5(2), 164-169.

[28] Rao K.S., Kartha K.N., Shrivastava S., Pandya S.S., Choubey U. (1988). In Proceeding of National Symposium on past, present and future of Bhopal lake, 55-65.

[29] Saxena R., Shrivastava P. (1989). A Check list of Fish fauna of Kunwari river (Tributary of Chambal river). North M.P. J. Inland Fish Soc.India 21(2): 41-44.

[30] Uchchariya D.K., Meenakshi Sexena and Saksena D.N. (2012). Fish biodiverisity of Tighra reservoir of Gwalior, Madhya Pradesh, India. Journal of Fisheries and Aquaculture, 3 (1): 37-43.

[31] Wilhm JL, Dorris TC. (1966). Species diversity of benthic macroinvertebrates in stream receiving domestic and oil refinery effluents. Amn. Midl. Nat. 76: 472-449. 